\title{
Review
}

\section{Application of Yeast to Study the Tau and Amyloid- $\beta$ Abnormalities of Alzheimer's Disease}

\author{
Afsaneh Porzoor and Ian G. Macreadie* \\ School of Applied Sciences, RMIT University, Bundoora, VIC, Australia
}

\begin{abstract}
The major molecules associated with Alzheimer's disease, the phosphorylated protein tau and the 42 amino acid peptide, amyloid- $\beta(A \beta)$, have recently been analyzed in yeast. These yeast studies have provided major new insights into the effects of tau and $A \beta$ and, at the same time, offered new approaches to rapidly search for chemicals that may be involved in prevention of Alzheimer's disease. The following review summarizes the role of yeast and its contribution in Alzheimer's disease research, and highlights important studies that have been conducted in this model organism.
\end{abstract}

Keywords: Alzheimer's disease, amyloid- $\beta$, Candida glabrata, Pichia pastoris, Saccharomyces cerevisiae, Schizosaccharomyces pombe, tau

\section{ALZHEIMER'S DISEASE}

Alzheimer's disease (AD) currently is an irreversible and progressive neurodegenerative disorder characterized by a decline in memory, intellect, comprehension, and learning capacity. It is an epidemic disease that most often occurs as an age-related disease. Among people of 80 years of age, AD affects $25 \%$. Currently over 35.6 million individuals worldwide live with this disease and it has been estimated that approximately 106 million people will suffer from AD by 2050 due to increasing longevity [1]. These attributes make it one of the biggest social burdens in the world.

$\mathrm{AD}$ results from death of neuronal cells and loss of synapses and is typified by extracellular plaques of amyloid- $\beta$ (A $\beta)$ and intracellular neurofibrillary

*Correspondence to: Ian G. Macreadie, School of Applied Sciences, RMIT University, Bundoora, VIC 3083, Australia. Tel.: +6139925 6627; Fax: +6139925 7110, E-mail: ian.macreadie@ rmit.edu.au. tangles of tau protein $[2,3]$. The strong association of $\mathrm{A} \beta$ and tau levels, combined with their toxicity, implicates them as causative agents in the development of AD.

There have been many approaches to try to cure or prevent AD. Some approaches are highly directed such as immunotherapy using both passive and active immunization $[4,5]$, while others involve dietary modification such as use of polyphenol and flavonoids found in plant extracts [6-9]. Many of the previous approaches for the treatment have been withdrawn due to their side effects and lack of efficacy [10]. Studies on AD mainly involve cell culture and transgenic mouse models, however, yeast studies are playing an increasing role in understanding $\mathrm{AD}$ and in designing chemo preventatives. This review summarizes some of the recent research conducted in yeast to study $\mathrm{AD}$ with a focus on tau and $A \beta$. Possible drugs and screening methods have also been listed. We have also attempted to recapitulate the advantages, disadvantages, and possible limitations of this model system. The main focus 
of this review is on Saccharomyces cerevisiae since most studies exploit this species. Where alternative species have been used, the names are given.

\section{YEAST AS A MODEL ORGANISM}

Yeast has a long history in biotechnology and currently provides valuable new biopharmaceuticals, including insulin and vaccines. Yeast has also provided basic insights to the broad field of biological science, including primary screening for the effect of chemicals, and expression of recombinant proteins. Although outcomes of any drug tests conducted in yeast should be validated with more physiologically relevant models, they still serve as a first line system to study many diseases. Some of these developments and how they have contributed to our knowledge of human health and disease are briefly outlined in Table 1.

Yeast are among the simplest eukaryotes and share many cellular mechanisms with all eukaryotic cells including humans. This is particularly true about the budding yeast $S$. cerevisiae. It has been the most manipulated and exploited species and has long been used as model organism for studying neurodegeneration (reviewed in [11-13]). It is also an established model organism for analyzing conserved cell death pathways such as apoptosis and necrosis [14]. Most processes involved in neurodegenerative disorders such as mitochondrial damage, oxidative stress, protein aggregation and degradation can be analyzed within yeast and often these can be coupled to high throughput screens [15].

Yeast has been used as a model organism since early $1950 \mathrm{~s}$, with the earliest studies providing an understanding of the mechanism of cell cycle and division (reviewed in [16]). It was the first eukaryotic organism to have its entire genome sequenced in 1996 [17]. Knowledge of that sequence combined with the knowledge of functions of many genes allowed a comparison to sequences of other genomes, including the human genome, where counterparts could be identified. It is recognized that around $30 \%$ of currently known genes involved in human disease have yeast orthologs [18].

\section{YEAST FOR AD: UNDERSTANDING A $\beta$ AND TAU}

Yeast are widely used for the heterologous expression of proteins associated with human disease and for expression of orthologues of proteins involved with human disease. The genes encoding the two main proteins/peptides implicated in $\mathrm{AD}$, tau and $\mathrm{A} \beta$, do not have orthologues in yeast but they can be expressed and studied in yeast. $A \beta$ has received considerable attention because of a wealth of data that implicate $A \beta$ in the development of AD. In particular, early onset or familial forms of $\mathrm{AD}$ (FAD) can occur as result of various amino acid changes in $A \beta$ (shown in Fig. 1).

$A \beta$ is generated through cleavage of amyloid$\beta$ protein precursor (A $\beta P P)$ by $\beta$-secretase (BACE) and $\gamma$-secretase. The cleavage products are extremely hydrophobic peptides that include $A \beta_{40}, A \beta_{42}$, and $\mathrm{A} \beta_{43}$, with the last two being more prone to aggregation and more neurotoxic while the former is found in greater concentration in FAD compared to the latter $[19,20]$. In this review our focus is on $A \beta_{42}$, which we abbreviate to $A \beta$.

In order to study $A \beta$, a few forms of these molecules are employed including chemically-synthesized $A \beta$, intracellular fused $A \beta$, and intracellular recombinant forms. Studies with chemically-synthesized $A \beta$ on Candida glabrata show an oligomerization-dependent cytotoxicity [21]. This phenomenon is now driving new approaches to block $A \beta$ toxicity through inhibition of this process. The in vivo oligomerization was observed when $A \beta$ was fused to yeast translational release factor, called MRF [22]. A $\beta$ caused oligomerization of MRF leading to loss of MRF function and growth,

Table 1

Major advances in yeast studies that had a valuable impact on human health and disease

\begin{tabular}{lc}
\hline Yeast advance & Impact on human biology \\
$\begin{array}{l}\text { The yeast genome was the first eukaryotic genome to be } \\
\text { sequenced [67] }\end{array}$ & $\begin{array}{c}\text { Human genes can be presumptively identified by similarity to yeast } \\
\text { counterparts } \\
\text { Complementation studies with human genes can be performed }\end{array}$ \\
$\begin{array}{l}\text { The yeast gene deletion collection is complete [68-71] } \\
\text { Yeast two hybrid is developed [72] }\end{array}$ & $\begin{array}{c}\text { Human protein interactions can be studied in yeast. Human gene libraries } \\
\text { are available for screening of human protein interactions }\end{array}$ \\
Reast three hybrid is developed [73] & $\begin{array}{l}\text { RN-protein interactions related to many human diseases (in particular } \\
\text { viral infections) can be studied. Receptors for small ligands can be } \\
\text { identified } \\
\text { Schizosaccharomyces pombe studies recognized as applicable to cancer } \\
\text { Studies on yeast cell cycle [74-80] }\end{array}$ \\
\end{tabular}




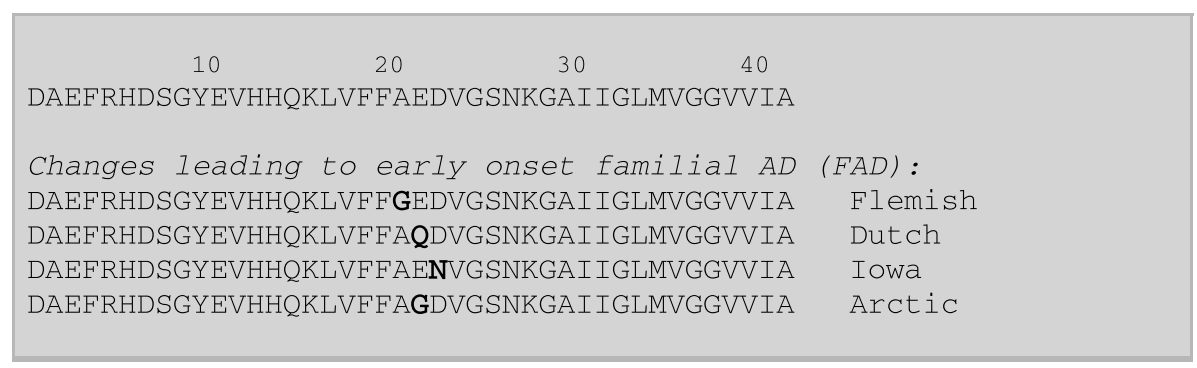

Fig. 1. Amino acid changes leading to the early onset of Alzheimer's disease. The amino acid sequence of A $\beta_{42}$ is given at the top. Amino acid changes in familial Alzheimer's disease have been highlighted in: Flemish mutation, causing angiopathy and patient frequently suffer from intracerebral hemorrhage stroke [96]; Dutch mutation, causing cerebral hemorrhage with amyloidosis and premature death [97]; Iowa mutation, causing cerebral amyloid angiopathy and occipital calcifications [98]; Arctic mutation, formation of plaques and tangle without any hemorrhage or stroke [99].

whereas compounds that blocked peptide aggregation led to growth. Similarly, Caine and colleagues [23] made fusions of green fluorescent protein (GFP) to $\mathrm{A} \beta$ to examine oligomerization in the context of the fusion protein. The purpose of this was to measure the amount of correctly folded fusion protein in vivo through its green fluorescence, while aggregation, oligomerization, and degradation of the fusion protein would lead to loss of fluorescence. It was found that relatively small fractions of cells exhibited fluorescence but the proportion of fluorescent cells was increased by treatment with a folate [24], a vitamin associated with AD chemo prevention. Also, intracellular expression of $A \beta$ fused to GFP was shown to be associated with reduction of yeast cell growth and an increase in the heat shock response (HSR) [23]. Increased HSR can provide protection of yeast cells from oxidative stress [25]. Yeast assays employing $A \beta$ fused to MRF and GFP appear very useful for monitoring effects of compounds that influence the oligomerization or half-life of $A \beta[26]$.

Yeast offers particular advantages for looking at inhibitors of $A \beta$ oligomerization. Subunits of human secretase complex such as A $\beta P P$ can be expressed and monitored individually in this model system. Yeast studies are inexpensive and convenient in comparison to in vitro studies of oligomerization with extremely expensive and variable batches of chemically-synthesized $A \beta$ that require denaturation immediately prior to use. Frequently $A \beta$ is abandoned and a surrogate peptide is used in its place. A second advantage of in vivo studies of inhibitors of $A \beta$ oligomerization is that compounds have to pass into the cell. The ability to pass through membranes is a definite requirement of any chemo preventative of $\mathrm{AD}$, since they are required to cross the blood-brain barrier and inhibit formation of toxic oligomers within the brain.
Thirdly, cytotoxic compounds fail the primary screening because they inhibit yeast growth and production of new $A \beta$. Hence, toxic molecules can be eliminated immediately. Fourthly, it is possible that compounds that act indirectly may be identified. Such compounds could include those that stimulate chaperones, or proteins that bind to $A \beta$. The contribution of yeast models to our understanding of AD is shown in Table 2.

It is known that intracellular $A \beta$ can be stabilized and is less toxic when fused to another protein, whereas extracellular $A \beta$ is highly toxic to the yeast cells. While $\mathrm{A} \beta$ fusions have advantages as outlined earlier, it is expected that fusions alter the properties of $A \beta$, so a very useful system is yeast producing native $A \beta$. In a recent study by D'Angelo and colleagues, intracellular trafficking pathways were found to be essential and a major determinant for the generation of toxic species of $\mathrm{A} \beta$ in $S$. cerevisiae regardless of whether $\mathrm{A} \beta$ was used alone or fused to GFP [27]. In transgenic mouse models for $\mathrm{AD}, \mathrm{A} \beta$ is produced by overproduction of human $\mathrm{A} \beta \mathrm{PP}$ and secretases [28, 29]. However, in S. cerevisiae the $A \beta$ production is a complication that does not occur due to lack of A $\beta P P$ and the two secretases ( $\beta$ - and $\gamma$-secretase), whereas all three endoproteases $(\alpha-, \beta-$, and $\gamma$-secretase) has been detected in Pichia pastoris [30].

Yeast can be made to produce native $A \beta$ using a simple constitutive expression system (Macreadie, unpublished). Yeast that produce $A \beta$ display a profound growth stress and there is a strong pressure to revert or suppress the effects. This is a useful attribute that can be exploited to provide knowledge about how a cell can overcome $A \beta$ toxicity. In addition, the growth stress which is due to $A \beta$ toxicity can be used in screening for compounds that inhibit that stress. Work is currently in progress in our laboratory to use these strains to identify novel chemo preventatives and to 
Table 2

Role of yeast in revealing some of the factors believed to contribute to the development of Alzheimer's disease

\begin{tabular}{ll}
\hline $\begin{array}{l}\text { Factors that may lead to development of } \\
\text { Alzheimer's disease }\end{array}$ & Yeast contribution \\
\hline $\mathrm{A} \beta$ oligomerization & $\begin{array}{c}\text { Two hybrid system; A } \beta \text { linked to LexA DNA binding domain and B42 } \\
\text { transactivation domain [81] } \\
\text { Expression of A } \beta / \text { Sup35p fusion protein [22, 82] } \\
\text { Expression of A } \beta / \text { GFP fusion protein [23] }\end{array}$ \\
& External A $\beta$ is toxic to $C$. glabrata cells [25, 83] \\
Yellular toxicity with external A $\beta$ & Yeast models expressing intracellular A $\beta$ [84] \\
Cellular toxicity with intracellular A $\beta$ & Identification of two aspartyl proteases, Yap3 and Mkc7 [85] \\
Reduction of $\alpha$-secretase cleavage of A $\beta P P$ & Yeast GAL reporter system [86] \\
& A $\beta P$ fused to invertase [87] \\
& Novel growth selection allowed human $\beta$-secretase to be detected [88] \\
$\beta$-secretase cleavage of A $\beta P P$ & Presenilin, nicastrin, APH-1. and PEN2 were identified as necessary components for \\
$\gamma$-secretase cleavage of A $\beta P P$ & $\gamma$ - secretase activity [89] \\
Tau hyperphosphorylation & Human tau 3-R and 4-R isoforms expressed in yeast [48, 52, 90] \\
\hline
\end{tabular}

elucidate how "known chemo preventatives" impact the toxicity.

Chemically-synthesized $\mathrm{A} \beta$ has been shown to be toxic to $C$. glabrata [21]. This has been an exciting development that further supports equivalent results in yeast and neuronal cells.

Neuronal cells are similarly affected. Neuronal cells are terminally differentiated cells and $A \beta$ stimulates cell division, which is a lethal event for them $[31,32]$. It is yet to be determined how A $\beta$ kills $C$. glabrata. In yeast, the toxicity assay is performed in water: $A \beta$ is added to cells in water and after 16 hours of incubation, cells are plated out to determine the viable colony count. In the absence of $A \beta$, cells in water remain quiescent for many days with no loss of viability. However, when a freshly prepared solution of $\mathrm{A} \beta$ is added, it binds the surface of the cells and kills them within hours. If the $A \beta$ is allowed to form fibrils, it is no longer toxic. A recent simulation study has shown that water can actually accelerate the fibril formation in the $A \beta$ peptide similar to any hydrophobic sequence whereas this process occurs more slowly in hydrophilic sequences [33]. Likewise, changes within $\mathrm{A} \beta$ itself that prevent oligomerization also block the toxic effect. Although $A \beta$ is generally regarded as a toxic molecule, the opposite effect has occasionally also been shown in both yeast and human cells. In C. glabrata, $\mathrm{A} \beta$ is protective from killing by sodium hydroxide toxicity [25], and with adult neuronal stem cells $A \beta$ can stimulate division [34].

In 1975, Weingarten and colleagues identified a protein factor named tau essential for microtubule assembly [35]. However, when tau is hyper-phosphorylated it caused formation of the neurofibrillary tangles which are aggregates of tau formed in the intracellular region.
Although, controversies and questions still surrounds toxicity of tau species [36], its presence has been identified as essential for $A \beta$-induced neurotoxicity [37]. Like $A \beta$, tangles are also associated with development of $\mathrm{AD}$ [38] as their presence impairs nutrient transport and perhaps cell signaling in the neuronal cells [39]. In fact, an interrelated relationship between $A \beta$ and tau has been reported whereby $A \beta$ accumulation triggers upstream events such as inflammation and oxidative stress leading to tau tangle formation and development of neurodegenerative disease [40].

Tau clearance and processing is normally mediated by both caspases and proteasome [41, 42] but in the hyperphosphorylated form, tau become resistant to the proteasome-mediated clearance $[40,43]$. However, previous studies have shown that oxidative stress by addition of millimolar concentrations of hydrogen peroxide $\left(\mathrm{H}_{2} \mathrm{O}_{2}\right)$ in primary oligodendrocyte culture of rat brain can result in dephosphorylation of tau [44] through activation of protein phosphatase 2A [45] and an increase in the activity of protein phosphatase 1 [46].

The tau-expressing yeast model for studying AD has been reviewed in depth previously [47]. S. cerevisiae has no known ortholog for human tau; however, human tau can be expressed in $S$. cerevisiae. Expression of various isoforms and mutant forms of tau in yeast has resulted in similar features and physiognomies to those of neuronal cells in $\mathrm{AD}$ [48, 49]. De Vos and colleagues have reported that tau aggregation in those yeast expressing human tau does not display a major tau-related growth phenotype [47]. However, tau-related growth phenotypes have not been reported in stationary phase yeast cells as the majority of previous studies have been conducted on exponentially growing cells [50]. Also, in a tau-GFP fusion 
assay, Timmers and associates found that yeast lack the microtubule binding site for tau whereas a common binding site for animal and plant were identified [51].

Many important yeast orthologs of tau phosphatases and kinases have been identified and are currently under investigation [48, 49, 52]. Further, expression of human tau in yeast has shown the presence of kinases which result in generating many phosphorylated and aggregated tau residues [52]. The phosphorylation of tau by yeast is due to the presence of Mds1 and Pho85 kinases which are orthologous of mammalian kinases Gsk-3 $\beta$ and Cdk5, respectively. Additionally, it appears that Pho85/Cdk5 has an inhibitory effect on Mds1/Gsk-3 $\beta$ activity in both mammalian [53] and yeast models [49]. Vanhelmont et al. also showed that induction of reactive oxygen species in yeast, through addition of $\mathrm{Fe}^{2+}$, caused an increase in formation of oligomers and aggregates of tau in the absence of phosphorylation [49].

\section{HIGH THROUGHPUT SCREENING FOR AD CHEMO PREVENTATIVES}

Impediments to research for a cure for $\mathrm{AD}$ have been due to a number of causes. A large setback is probably due to the huge reliance on animal models which have provided fewer leads on chemo preventatives than epidemiological studies. Another difficulty is recognition of the early markers in the disease pathway.

Therapeutic strategies and approaches that have been developed to date include those with antiinflammatory, anti-amyloid formation or stability, and antioxidant properties. Many compounds and chemicals have provided promising results in cell culture and animal models of AD. A list of some of these modulating compounds that have shown potential benefit in yeast models have been specified in Table 3 .

Microbial models are useful in the screening of AD drugs since they offer an ability to screen large numbers of compounds in short time periods $[26,54$,
55]. They can interrogate compounds that affect $A \beta$ oligomer formation as well as killing and toxicity. Wurth and colleagues have developed an Escherichia coli that produces A $\beta$ fused to GFP and have used it to identify candidates for AD chemo preventatives [56]. Although, it has some useful attributes like the yeast model regarding its maintenance and cost, E. coli lacks many of the human orthologous proteins that may be identified in the yeast screening. Yeast are far simpler than humans but this simplicity allows for better understanding the cellular mechanism and pathways to be studied in depth. For instance, Treusch and associates have taken advantage of this simplicity and have conducted genome-wide overexpression in order to screen for toxicity modulators in yeast models which resulted in identification of several toxicity suppressors including the yeast homolog of phosphatidylinositol binding clathrin assembly protein (PICALM) and other endocytic factors that have role in $\mathrm{AD}$ [57]. The authors also show that after screening 5,000 genes with the aim of finding $A \beta$ toxicity modifiers, they have identified 12 with human homologs, further implicating the benefit of yeast models in the genome-wide association studies. In a similar way, López and colleagues after screening two commercial chemical libraries have identified four compounds capable of inhibiting $\mathrm{A} \beta$ aggregation in S. cerevisiae and Podospora anserine [58].

Thousands of human genes and proteins have counterparts in yeast, and the "housekeeping" functions, including defense mechanisms are highly similar. Therefore compounds that interact with yeast cellular processes are likely to act in the same way on human cellular processes. Some of these cellular processes include responses to reactive oxygen species, protein misfolding, and apoptosis. In cases where there are substantial differences between the two, re-engineered yeast that can produce both A $\beta P P$ and $\gamma$-secretase can be used. Indeed yeast can also be used for screening of inhibitors of $\beta$-secretases [59, 60].

Aging has been known as one of most important factors for development of $\mathrm{AD}$ and that $\mathrm{A} \beta$ can induce

Table 3

Selected number of chemicals/compounds tested in S. cerevisiae that may have benefits for treatment and prevention of AD and other age-related diseases

\begin{tabular}{|c|c|c|}
\hline Chemical/compound & Findings & References \\
\hline Resveratrol & Increased cell survival through stimulation of Sir-2 and increased DNA stability & [91] \\
\hline Quercetin & $\begin{array}{l}\text { Increased cell protection due to reduction in reactive oxygen species production, } \\
\text { glutathione oxidation, protein carbonylation, and lipid peroxidation }\end{array}$ & [92] \\
\hline Clioquinol & Affected metal (e.g., copper, iron, zinc) homeostasis & [93] \\
\hline Curcumin & $\begin{array}{l}\text { Chelated metal ions such as copper and iron, possibly preventing metal-mediated } \\
\text { toxicity of neuronal cells }\end{array}$ & [94] \\
\hline Latrepirdine (Dimebon ${ }^{\mathrm{TM}}$ ) & Increased autophagy and degradation of $A \beta$ & [95] \\
\hline
\end{tabular}


cell cycle events in the post-mitotic neuronal cells which have been terminally differentiated. According to previous studies, age-dependent diseases can be investigated in both $S$. cerevisiae and Schizosaccharomyces pombe by altering the growth conditions and analyzing chronological lifespan or post-diauxic phase [61]. This was achieved by growing cells into either stationary or exponential phase, with the stationary phase being more representative of the aged cells similar to the post-mitotic neuronal cells $[62,63]$. Although such studies have generated invaluable data on chronological aging and regulatory pathways $[64,65]$, it is important to distinguish differences between senescence and quiescence. Senescence occurs in terminally differentiated neuronal cells, and age-related diseases and refers to permanent proliferative cell cycle arrest (reviewed in [66]), whereas quiescence is a reversible event that occurs in those cells temporary arrested in cycle due to trauma or stress induced by environment. Another limitation of yeast models is the simplicity of surrounding environment and the absence of inflammation, differentiation, and migration which is triggered by $\mathrm{A} \beta$ in neuronal cells.

For S. cerevisiae, collections of gene deletant strains are readily available and deletions in other species can also be made to study the gene-specific neurotoxic effects. Additionally, S. cerevisiae strains producing tau or $A \beta$ can be analyzed by gene arrays to determine effects on expression. Proteomic analyses may also help to identify host proteins that modulate the toxic effect and cell death.

Neuronal cells are also highly specific, complex, differentiated cells with a unique morphology of dendrites, axons, and synapses that changes with the progression of $\mathrm{AD}$, as well as through the effects of their surrounding environment. Yeast cells on the other hand are not differentiated in the same way, and they can be quite adaptive and survive altered conditions. However, it should be noted that less complexity in this situation can be viewed as an advantage since cDNA libraries of yeast genes are readily available which can make molecular analyses easier. Furthermore, despite the fact $S$. cerevisiae does not carry any homologous neurotoxic protein, conserved molecular interactions mimic similar pathways of function and transport.

\section{CONCLUDING REMARKS}

Powerful approaches in yeast technologies are now being applied to the study of AD. Focusing on tau and
$\mathrm{A} \beta$, results can be obtained in hours, leading to new insights about how these molecules contribute to disease progression in the brain. Further, the immense power of genomic, proteomic, and metabolomic tools can readily be employed in yeast studies to gain a complete understanding of how tau and $A \beta$ exert their effects. Coupled with this is the ability of high throughput screening approaches in yeast that can readily identify molecules that inhibit oligomerization or the toxic effects of these compounds.

\section{ACKNOWLEDGMENTS}

We thank The Medical Advances Without Animals Trust (MAWA), which aims to advance medical science and improve human health and therapeutic interventions without using animals or animal products for providing funds to make this an open access article.

Authors' disclosures available online (http://www.jalz.com/disclosures/view.php?id=1647).

\section{REFERENCES}

[1] World Health Organisation (2012) News Release: Dementia cases set to triple by 2050 but still largely ignored. WHO, Geneva, http://www.who.int/mediacentre/news/releases/2012 /dementia_20120411/en/

[2] Irie K, Murakami K, Masuda Y, Morimoto A, Ohigashi H, Ohashi R, Takegoshi K, Nagao M, Shimizu T, Shirasawa $\mathrm{T}$ (2005) Structure of $\beta$-amyloid fibrils and its relevance to their neurotoxicity: Implications for the pathogenesis of Alzheimer's disease. J Biosci Bioeng 99, 437-447.

[3] Kamenetz F, Tomita T, Hsieh H, Seabrook G, Borchelt D, Iwatsubo T, Sisodia S, Malinow R (2003) APP processing and synaptic function. Neuron 37, 925-937.

[4] Qu B, Boyer PJ, Johnston SA, Hynan LS, Rosenberg RN (2006) A $\beta 42$ gene vaccination reduces brain amyloid plaque burden in transgenic mice. J Neurol Sci 244, 151-158.

[5] Solomon B, Frenkel D (2010) Immunotherapy for Alzheimer's disease. Neuropharmacology 59, 303-309.

[6] Berhanu WM, Masunov AE (2010) Natural polyphenols as inhibitors of amyloid aggregation. Molecular dynamics study of GNNQQNY heptapeptide decamer. Biophys Chem 149, 12-21.

[7] Misiti F, Sampaolese B, Mezzogori D, Orsini F, Pezzotti M, Giardina B, Clementi ME (2006) Protective effect of rhubarb derivatives on amyloid beta (1-42) peptide-induced apoptosis in IMR-32 cells: A case of nutrigenomic. Brain Res Bull 71, 29-36.

[8] Nakdook W, Khongsombat O, Taepavarapruk P, Taepavarapruk N, Ingkaninan K (2010) The effects of Tabernaemontana divaricata root extract on amyloid $\beta$-peptide $25-35$ peptides induced cognitive deficits in mice. J Ethnopharmacol 130, 122-126. 
[9] Wang H-Q, Sun X-B, Xu Y-X, Zhao H, Zhu Q-Y, Zhu C-Q (2010) Astaxanthin upregulates heme oxygenase-1 expression through ERK1/2 pathway and its protective effect against beta-amyloid-induced cytotoxicity in SH-SY5Y cells. Brain Res 1360, 159-167.

[10] Selkoe DJ, Schenk D (2003) Alzheimer's disease: Molecular understanding predicts amyloid-based therapeutics. Аппи Rev Pharmacol Toxicol 43, 545-584.

[11] Khurana V, Lindquist S (2010) Modelling neurodegeneration in Saccharomyces cerevisiae: Why cook with baker's yeast? Nat Rev Neurosci 11, 436-449.

[12] Pereira C, Bessa C, Soares J, Leao M, Saraiva L (2012) Contribution of yeast models to neurodegeneration research. $J$ Biomed Biotechnol 2012, 941232.

[13] Vishnevskaia AB, Kushnirov VV, Ter-Avanesian MD (2007) Neurodegenerative amyloidoses: The yeast model. Mol Biol (Mosk) 41, 346-354.

[14] Braun RJ, Büttner S, Ring J, Kroemer G, Madeo F (2010) Nervous yeast: Modeling neurotoxic cell death. Trends Biochem Sci 35, 135-144.

[15] Mager WH, Winderickx J (2005) Yeast as a model for medical and medicinal research. Trends Pharmacol Sci 26, 265-273.

[16] Wittenberg C, Reed SI (2005) Cell cycle-dependent transcription in yeast: Promoters, transcription factors, and transcriptomes. J Oncogene 24, 2746-2755.

[17] Goffeau A, Barrell BG, Bussey H, Davis RW, Dujon B, Feldmann H, Galibert F, Hoheisel JD, Jacq C, Johnston M, Louis EJ, Mewes HW, Murakami Y, Philippsen P, Tettelin H, Oliver SG (1996) Life with 6000 genes. Science 274, 546, 563-547.

[18] Foury F (1997) Human genetic diseases: A cross-talk between man and yeast. Gene 195, 1-10.

[19] McGowan E, Pickford F, Kim J, Onstead L, Eriksen J, Yu C, Skipper L, Murphy MP, Beard J, Das P, Jansen K, DeLucia M, Lin W-L, Dolios G, Wang R, Eckman CB, Dickson DW, Hutton M, Hardy J, Golde T (2005) A $\beta 42$ is essential for parenchymal and vascular amyloid deposition in mice. Neuron 47, 191-199.

[20] Saito T, Suemoto T, Brouwers N, Sleegers K, Funamoto S, Mihira N, Matsuba Y, Yamada K, Nilsson P, Takano J, Nishimura M, Iwata N, Van Broeckhoven C, Ihara Y, Saido TC (2011) Potent amyloidogenicity and pathogenicity of A $\beta 43$. Nat Neurosci 14, 1023-1032.

[21] Bharadwaj P, Waddington L, Varghese J, Macreadie IG (2008) A new method to measure cellular toxicity of non-fibrillar and fibrillar Alzheimer's A $\beta$ using yeast. J Alzheimers Dis 13, 147-150.

[22] Bagriantsev S, Liebman S (2006) Modulation of A $\beta 42$ low$\mathrm{n}$ oligomerization using a novel yeast reporter system. $B M C$ Biol 4, 32.

[23] Caine J, Sankovich S, Antony H, Waddington L, Macreadie P, Varghese J, Macreadie I (2007) Alzheimer's A $\beta$ fused to green fluorescent protein induces growth stress and a heat shock response. FEMS Yeast Res 7, 1230-1236.

[24] Macreadie I, Lotfi-Miri M, Mohotti S, Shapira D, Bennett L, Varghese J (2008) Validation of folate in a convenient yeast assay suited for identification of inhibitors of Alzheimer's A $\beta$ aggregation. J Alzheimers Dis 15, 391-396.

[25] Dubey AK, Bharadwaj PR, Varghese JN, Macreadie IG (2009) Alzheimer's A $\beta$ rescues yeast from hydroxide toxicity. J Alzheimers Dis 18, 31-33.

[26] Park SK, Pegan SD, Mesecar AD, Jungbauer LM, LaDu MJ, Liebman SW (2011) Development and validation of a yeast high-throughput screen for inhibitors of A $\beta 42$ oligomerization. Dis Model Mech 4, 822-831.
[27] D'Angelo F, Vignaud H, Di Martino J, Salin B, Devin A, Cullin C, Marchal C (2013) A yeast model for amyloid- $\beta$ aggregation exemplifies the role of membrane trafficking and PICALM in cytotoxicity. Dis Model Mech 6, 206-216.

[28] Games D, Adams D, Alessandrini R, Barbour R, Borthelette P, Blackwell C, Carr T, Clemens J, Donaldson T, Gillespie F, Guido T, Hagopian S, Johnson-Wood K, Khan K, Lee M, Leibowitz P, Lieberburg I, Little S, Masliah E, McConlogue L, Montoya-Zavala M, Mucke L, Paganini L, Penniman E, Power M, Schenk D, Seubert P, Snyder B, Soriano F, Tan H, Vitale J, Wadsworth S, Wolozin B, Zhao J (1995) Alzheimer-type neuropathology in transgenic mice overexpressing V717F $\beta$-amyloid precursor protein. Nature 373, 523-527.

[29] Goate A, Chartier-Harlin M-C, Mullan M, Brown J, Crawford F, Fidani L, Giuffra L, Haynes A, Irving N, James L, Mant R, Newton P, Rooke K, Roques P, Talbot C, Pericak-Vance M, Roses A, Williamson R, Rossor M, Owen M, Hardy J (1991) Segregation of a missense mutation in the amyloid precursor protein gene with familial Alzheimer's disease. Nature 349, 704-706.

[30] Le Brocque D, Henry A, Cappai R, Li QX, Tanner JE, Galatis D, Gray C, Holmes S, Underwood JR, Beyreuther K, Masters CL, Evin G (1998) Processing of the Alzheimer's disease amyloid precursor protein in Pichia pastoris: Immunodetection of $\alpha-, \beta-, \gamma$-secretase products. Biochemistry 37, 14958-14965.

[31] Ding XL, Husseman J, Tomashevski A, Nochlin D, Jin LW, Vincent I (2000) The cell cycle Cdc25A tyrosine phosphatase is activated in degenerating postmitotic neurons in Alzheimer's disease. Am J Pathol 157, 1983-1990.

[32] Mosch B, Morawski M, Mittag A, Lenz D, Tarnok A, Arendt T (2007) Aneuploidy and DNA replication in the normal human brain and Alzheimer's disease. J Neurosci 27, 68596867.

[33] Thirumalai D, Reddy G, Straub JE (2012) Role of water in protein aggregation and amyloid polymorphism. Acc Chem Res 45, 83-92.

[34] Heo C, Chang KA, Choi HS, Kim HS, Kim S, Liew H, Kim JA, Yu E, Ma J, Suh YH (2007) Effects of the monomeric, oligomeric, and fibrillar A $\beta 42$ peptides on the proliferation and differentiation of adult neural stem cells from subventricular zone. J Neurochem 102, 493-500.

[35] Weingarten MD, Lockwood AH, Hwo SY, Kirschner MW (1975) A protein factor essential for microtubule assembly. Proc Natl Acad Sci U S A 72, 1858-1862.

[36] Le Corre S, Klafki HW, Plesnila N, Hubinger G, Obermeier A, Sahagun H, Monse B, Seneci P, Lewis J, Eriksen J, Zehr C, Yue M, McGowan E, Dickson DW, Hutton M, Roder HM (2006) An inhibitor of tau hyperphosphorylation prevents severe motor impairments in tau transgenic mice. Proc Natl Acad Sci U S A 103, 9673-9678.

[37] Rapoport M, Dawson HN, Binder LI, Vitek MP, Ferreira A (2002) Tau is essential to $\beta$-amyloid-induced neurotoxicity. Proc Natl Acad Sci U S A 99, 6364-6369.

[38] Zabrocki P, Pellens K, Vanhelmont T, Vandebroek T, Griffioen G, Wera S, Van Leuven F, Winderickx J (2005) Characterization of $\alpha$-synuclein aggregation and synergistic toxicity with protein tau in yeast. FEBS J 272, 1386-1400.

[39] Vega IE, Traverso EE, Ferrer-Acosta Y, Matos E, Colon M, Gonzalez J, Dickson D, Hutton M, Lewis J, Yen SH (2008) A novel calcium-binding protein is associated with tau proteins in tauopathy. J Neurochem 106, 96-106.

[40] Oddo S, Billings L, Kesslak JP, Cribbs DH, LaFerla FM (2004) A $\beta$ immunotherapy leads to clearance of early, but not 
late, hyperphosphorylated tau aggregates via the proteasome. Neuron 43, 321-332.

[41] David DC, Layfield R, Serpell L, Narain Y, Goedert M, Spillantini MG (2002) Proteasomal degradation of tau protein. J Neurochem 83, 176-185.

[42] Goldbaum O, Oppermann M, Handschuh M, Dabir D, Zhang B, Forman MS, Trojanowski JQ, Lee VM, Richter-Landsberg C (2003) Proteasome inhibition stabilizes tau inclusions in oligodendroglial cells that occur after treatment with okadaic acid. J Neurosci 23, 8872-8880.

[43] Poppek D, Keck S, Ermak G, Jung T, Stolzing A, Ullrich O, Davies KJ, Grune T (2006) Phosphorylation inhibits turnover of the tau protein by the proteasome: Influence of RCAN1 and oxidative stress. Biochem J 400, 511-520.

[44] LoPresti P, Konat GW (2001) Hydrogen peroxide induces transient dephosphorylation of tau protein in cultured rat oligodendrocytes. Neurosci Lett 311, 142-144.

[45] Galas MC, Dourlen P, Begard S, Ando K, Blum D, Hamdane M, Buee L (2006) The peptidylprolyl cis/trans-isomerase Pin1 modulates stress-induced dephosphorylation of tau in neurons. Implication in a pathological mechanism related to Alzheimer disease. J Biol Chem 281, 19296-19304.

[46] Zambrano CA, Egana JT, Nunez MT, Maccioni RB, Gonzalez-Billault C (2004) Oxidative stress promotes tau dephosphorylation in neuronal cells: The roles of cdk5 and PP1. Free Radic Biol Med 36, 1393-1402.

[47] De Vos A, Anandhakumar J, Van den Brande J, Verduyckt M, Franssens V, Winderickx J, Swinnen E (2011) Yeast as a model system to study tau biology. Int J Alzheimers Dis 2011, 428970.

[48] Vandebroek T, Terwel D, Vanhelmont T, Gysemans M, Van Haesendonck C, Engelborghs Y, Winderickx J, Van Leuven F (2006) Microtubule binding and clustering of human Tau$4 \mathrm{R}$ and Tau-P301L proteins isolated from yeast deficient in orthologues of glycogen synthase kinase- $3 \beta$ or cdk5. J Biol Chem 281, 25388-25397.

[49] Vanhelmont T, Vandebroek T, De Vos A, Terwel D, Lemaire K, Anandhakumar J, Franssens V, Swinnen E, Van Leuven F, Winderickx J (2010) Serine-409 phosphorylation and oxidative damage define aggregation of human protein tau in yeast. FEMS Yeast Res 10, 992-1005.

[50] Bretteville A, Planel E (2008) Tau aggregates: Toxic, inert, or protective species? J Alzheimers Dis 14, 431-436.

[51] Timmers AC, Niebel A, Balague C, Dagkesamanskaya A (2002) Differential localisation of GFP fusions to cytoskeleton-binding proteins in animal, plant, and yeast cells. Protoplasma 220, 69-78.

[52] Vandebroek $\mathrm{T}$, Vanhelmont $\mathrm{T}$, Terwel $\mathrm{D}$, Borghgraef $\mathrm{P}$, Lemaire K, Snauwaert J, Wera S, Van Leuven F, Winderickx J (2005) Identification and isolation of a hyperphosphorylated, conformationally changed intermediate of human protein tau expressed in yeast. Biochemistry 44, 1146611475.

[53] Wen Y, Planel E, Herman M, Figueroa HY, Wang L, Liu L, Lau LF, Yu WH, Duff KE (2008) Interplay between cyclindependent kinase 5 and glycogen synthase kinase $3 \beta$ mediated by neuregulin signaling leads to differential effects on tau phosphorylation and amyloid precursor protein processing. $J$ Neurosci 28, 2624-2632.

[54] Nemavarkar P, Chourasia BK, Pasupathy K (2004) Evaluation of radioprotective action of compounds using Saccharomyces cerevisiae. J Environ Pathol Toxicol Oncol 23, 145-151.

[55] Nemavarkar PS, Chourasia BK, Pasupathy K (2004) Detection of gamma-irradiation induced DNA damage and radioprotection of compounds in yeast using comet assay. $J$ Radiat Res 45, 169-174.

[56] Wurth C, Guimard NK, Hecht MH (2002) Mutations that reduce aggregation of the Alzheimer's A $\beta 42$ peptide: An unbiased search for the sequence determinants of $A \beta$ amyloidogenesis. J Mol Biol 319, 1279-1290.

[57] Treusch S, Hamamichi S, Goodman JL, Matlack KE, Chung CY, Baru V, Shulman JM, Parrado A, Bevis BJ, Valastyan JS, Han H, Lindhagen-Persson M, Reiman EM, Evans DA, Bennett DA, Olofsson A, DeJager PL, Tanzi RE, Caldwell KA, Caldwell GA, Lindquist S (2011) Functional links between $A \beta$ toxicity, endocytic trafficking, and Alzheimer's disease risk factors in yeast. Science 334, 1241-1245.

[58] Lopez LC, Dos-Reis S, Espargaro A, Carrodeguas JA, Maddelein ML, Ventura S, Sancho J (2012) Discovery of novel inhibitors of amyloid $\beta$-peptide 1-42 aggregation. J Med Chem 55, 9521-9530.

[59] Middendorp O, Ortler C, Neumann U, Paganetti P, Luthi U, Barberis A (2004) Yeast growth selection system for the identification of cell-active inhibitors of $\beta$-secretase. Biochim Biophys Acta 1674, 29-39.

[60] Middendorp O, Luthi U, Hausch F, Barberis A (2004) Searching for the most effective screening system to identify cell-active inhibitors of $\beta$-secretase. Biol Chem 385, 481-485.

[61] Fabrizio P, Longo VD (2008) Chronological aging-induced apoptosis in yeast. Biochim Biophys Acta 1783, 1280-1285.

[62] Buttner S, Bitto A, Ring J, Augsten M, Zabrocki P, Eisenberg T, Jungwirth H, Hutter S, Carmona-Gutierrez D, Kroemer G, Winderickx J, Madeo F (2008) Functional mitochondria are required for $\alpha$-synuclein toxicity in aging yeast. $J$ Biol Chem 283, 7554-7560.

[63] McMurray MA, Gottschling DE (2004) Aging and genetic instability in yeast. Curr Opin Microbiol 7, 673-679.

[64] Fabrizio P, Longo VD (2003) The chronological life span of Saccharomyces cerevisiae. Aging Cell 2, 73-81.

[65] Fabrizio P, Pozza F, Pletcher SD, Gendron CM, Longo VD (2001) Regulation of longevity and stress resistance by Sch9 in yeast. Science 292, 288-290.

[66] Sikora E, Arendt T, Bennett M, Narita M (2011) Impact of cellular senescence signature on ageing research. Ageing Res Rev 10, 146-152.

[67] Churcher C, Bowman S, Badcock K, Bankier A, Brown D, Chillingworth T, Connor R, Devlin K, Gentles S, Hamlin N, Harris D, Horsnell T, Hunt S, Jagels K, Jones M, Lye G, Moule S, Odell C, Pearson D, Rajandream M, Rice P, Rowley N, Skelton J, Smith V, Barrell B, et al. (1997) The nucleotide sequence of Saccharomyces cerevisiae chromosome IX. Nature 387, 84-87.

[68] Bach S, Talarek N, Andrieu T, Vierfond J-M, Mettey Y, Galons H, Dormont D, Meijer L, Cullin C, Blondel M (2003) Isolation of drugs active against mammalian prions using a yeast-based screening assay. Nat Biotechnol 21, 1075-1081.

[69] Pimentel C, Batista-Nascimento L, Rodrigues-Pousada C, Menezes RA (2012) Oxidative stress in Alzheimer's and Parkinson's diseases: Insights from the yeast Saccharomyces cerevisiae. Oxid Med Cell Longev 2012, 132146.

[70] Vidan S, Snyder M (2001) Large-scale mutagenesis: yeast genetics in the genome era. Curr Opin Biotechnol 12, 28-34.

[71] Tong AH, Evangelista M, Parsons AB, Xu H, Bader GD, Page N, Robinson M, Raghibizadeh S, Hogue CW, Bussey H, Andrews B, Tyers M, Boone C (2001) Systematic genetic analysis with ordered arrays of yeast deletion mutants. Science 294, 2364-2368. 
[72] Fields S, Song O (1989) A novel genetic system to detect protein-protein interactions. Nature 340, 245-246.

[73] SenGupta DJ, Zhang B, Kraemer B, Pochart P, Fields S, Wickens M (1996) A three-hybrid system to detect RNAprotein interactions in vivo. Proc Natl Acad Sci USA 93, 8496-8501.

[74] Culotti J, Hartwell LH (1971) Genetic control of the cell division cycle in yeast: III. Seven genes controlling nuclear division. Exp Cell Res 67, 389-401.

[75] Emili A, Schieltz DM, Yates Iii JR, Hartwell LH (2001) Dynamic interaction of DNA damage checkpoint protein Rad53 with chromatin assembly factor Asf1. Mol Cell 7, 13-20.

[76] Hartwell L (1992) Defects in a cell cycle checkpoint may be responsible for the genomic instability of cancer cells. Cell 71, 543-546.

[77] Hartwell LH (1971) Genetic control of the cell division cycle in yeast: IV. Genes controlling bud emergence and cytokinesis. Exp Cell Res 69, 265-276.

[78] Müller B, Grossniklaus U (2010) Model organisms — A historical perspective. J Proteomic 73, 2054-2063.

[79] Paulovich AG, Toczyski DP, Hartwell LH (1997) When checkpoints fail. Cell 88, 315-321.

[80] Simon JA, Bedalov A (2004) Yeast as a model system for anticancer drug discovery. Nat Rev Cancer 4, 481-487.

[81] Hughes SR, Goyal S, Sun JE, Gonzalez-DeWhitt P, Fortes MA, Riedel NG, Sahasrabudhe SR (1996) Two-hybrid system as a model to study the interaction of beta-amyloid peptide monomers. Proc Natl Acad Sci U S A 93, 2065-2070.

[82] von der Haar T, Josse L, Wright P, Zenthon J, Tuite MF (2007) Development of a novel yeast cell-based system for studying the aggregation of Alzheimer's disease-associated A $\beta$ peptides in vivo. Neurodegener Dis 4, 136-147.

[83] Simakova O, Arispe NJ (2006) Early and late cytotoxic effects of external application of the Alzheimer's A $\beta$ result from the initial formation and function of $\mathrm{A} \beta$ ion channels. Biochemistry 45, 5907-5915.

[84] LaFerla FM, Green KN, Oddo S (2007) Intracellular A $\beta$ in Alzheimer's disease. Nat Rev Neurosci 8, 499-509.

[85] Zhang W, Espinoza D, Hines V, Innis M, Mehta P, Miller DL (1997) Characterization of $\beta$-amyloid peptide precursor processing by the yeast Yap3 and Mkc7 proteases. Biochim Biophys Acta 1359, 110-122.

[86] Gunyuzlu PL, White WH, Davis GL, Hollis GF, Toyn JH (2000) A yeast genetic assay for caspase cleavage of the A $\beta$ precursor protein. Mol Biotechnol 15, 29-37.

[87] Luthi U, Schaerer-Brodbeck C, Tanner S, Middendorp O, Edler K, Barberis A (2003) Human $\beta$-secretase activity in yeast detected by a novel cellular growth selection system. Biochim Biophys Acta 1620, 167-178.

[88] Lüthi U, Schaerer-Brodbeck C, Tanner S, Middendorp O, Edler K, Barberis A (2003) Human $\beta$-secretase activity in yeast detected by a novel cellular growth selection system. Biochim Biophys Acta 1620, 167-178.

[89] Edbauer D, Winkler E, Regula JT, Pesold B, Steiner H, Haass C (2003) Reconstitution of $\gamma$-secretase activity. Nat Cell Biol 5, 486-488.

[90] Vandebroek T, Terwel D, Vanhelmont T, Winderickx J, Van Leuven F (2005) Phosphorylation and aggregation of protein tau in humanized yeast cells and in transgenic mouse brain. In New Trends in Alzheimer and Parkinson Related Disorders: ADPD. Medimond, pp. 15-19, http://med. kuleuven.be/legtegg/Publications/pub0101/pdf0101.pdf

[91] Howitz KT, Bitterman KJ, Cohen HY, Lamming DW, Lavu S, Wood JG, Zipkin RE, Chung P, Kisielewski A, Zhang LL, Scherer B, Sinclair DA (2003) Small molecule activators of sirtuins extend Saccharomyces cerevisiae lifespan. Nature 425, 191-196.

[92] Belinha I, Amorim MA, Rodrigues P, de Freitas V, MoradasFerreira P, Mateus N, Costa V (2007) Quercetin increases oxidative stress resistance and longevity in Saccharomyces cerevisiae. J Agric Food Chem 55, 2446-2451.

[93] Li C, Wang J, Zhou B (2010) The metal chelating and chaperoning effects of clioquinol: Insights from yeast studies. $J$ Alzheimers Dis 21, 1249-1262.

[94] Minear S, O’Donnell AF, Ballew A, Giaever G, Nislow C, Stearns T, Cyert MS (2011) Curcumin inhibits growth of Saccharomyces cerevisiae through iron chelation. Eukaryot Cell 10, 1574-1581.

[95] Bharadwaj PR, Verdile G, Barr RK, Gupta V, Steele JW, Lachenmayer ML, Yue Z, Ehrlich ME, Petsko G, Ju S, Ringe D, Sankovich SE, Caine JM, Macreadie IG, Gandy S, Martins RN (2012) Latrepirdine (Dimebon) enhances autophagy and reduces intracellular GFP-A $\beta 42$ levels in yeast. $J$ Alzheimers Dis 32, 949-967.

[96] Hendriks L, van Duijn CM, Cras P, Cruts M, Van Hul W, van Harskamp F, Warren A, McInnis MG, Antonarakis SE, Martin JJ, et al. (1992) Presenile dementia and cerebral haemorrhage linked to a mutation at codon 692 of the $\beta$-amyloid precursor protein gene. Nat Genet 1, 218-221.

[97] Levy E, Carman MD, Fernandez-Madrid IJ, Power MD, Lieberburg I, van Duinen SG, Bots GT, Luyendijk W, Frangione B (1990) Mutation of the Alzheimer's disease amyloid gene in hereditary cerebral hemorrhage, Dutch type. Science 248, 1124-1126.

[98] Grabowski TJ, Cho HS, Vonsattel JP, Rebeck GW, Greenberg SM (2001) Novel amyloid precursor protein mutation in an Iowa family with dementia and severe cerebral amyloid angiopathy. Ann Neurol 49, 697-705.

[99] Nilsberth C, Westlind-Danielsson A, Eckman CB, Condron MM, Axelman K, Forsell C, Stenh C, Luthman J, Teplow DB, Younkin SG, Naslund J, Lannfelt L (2001) The 'Arctic' APP mutation (E693G) causes Alzheimer's disease by enhanced A $\beta$ protofibril formation. Nat Neurosci 4, 887-893. 